\title{
PENGEMBANGAN KEBERAGAMAAN PESERTA DIDIK MELALUI BUDAYA AGAMA DI SMPN 10 BANDUNG
}

\section{DEVELOPMENT OF RELIGIOUS LEARNERS THROUGH RELIGIOUS CULTURE IN SMPN 10 BANDUNG}

\author{
Ulfah Azqia Mupidah \\ e-mail : ulfaazqiamufidah@gmail.com \\ SMP Negeri 10 Bandung \\ Nani Rohaeni \\ e-mail : naniuninuss3sim25@gmail.com \\ Kamenag Kabupaten Bandung \\ Taufikurohman \\ e-mail : taufikurohman @uisgd.ac.id \\ UIN Sunan Gunung Djati Bandung
}

\begin{abstract}
Abstrak
Tujuan dari penelitian ini adalah untuk menggambarkan perkembangan agama mahasiswa yang mencari perkembangan budaya agama di SMP Negeri 10 Bandung. Hasil penelitian menunjukkan bahwa pelaksanaan pembinaan keagamaan siswa melalui pengembangan budaya keagamaan di SMP Negeri 10 Bandung telah berjalan dengan baik dan terprogram, baik yang dilakukan oleh sekolah sebagai lembaga pendidikan yang utuh dengan hikmah yang berkaitan dengan perkembangan budaya keagamaan di sekolah dan kegiatan masyarakat yang dilakukan oleh Rohis (Spiritual Islam) sebagai semacam kegiatan ekstrakurikuler sekolah khusus keteduhan. kegiatan keagamaan lainnya. Keberhasilan ini dapat dicapai karena upaya kepala sekolah dan dukungan dari seluruh komunitas sekolah dengan menunjukkan komitmen yang masing-masing terjadi bersama dan saling mendukung.
\end{abstract}

Kata kunci: Perkembangan agama, budaya agama.

\begin{abstract}
The purpose of the study was to describe the religious development student trought the development of religious culture at SMP Negeri 10 Bandung. The result of the study showed that the implementation of coaching student's religious through the development of religious culture at SMP Negeri 10 Bandung has been going well and programmed, both conducted by the school as an educational institution that is intact with the wisdom which relate to the development of the religious culture in school and community activities undertaken by Rohis (The Spiritual of Islam) as a kind of special school extracurricular activities shade other religious activities. This success can be achieved due to the efforts of the principal and the support of the entire school community by showing commitment each of which takes place together and support each other.
\end{abstract}

Keywords: Religious development, Religious culture 
Submitted : 11-11-2021 | Accepted : 20-12-2021 | Published : 26-12-2021

\section{PENDAHULUAN}

Pendidikan memegang peranan yang sangat penting dalam proses peningkatan kualitas Sumber Daya Manusia (SDM). Dalam dunia pendidikan, sekolah merupakan salah satu wadah dimana proses Transfer of knowledge berlangsung. Proses pengajaran dan pembelajaran di sekolah diharapkan mampu memperjuangkan dan mewujudkan pendidikan di Indonesia yang berkualitas.

Kesadaran akan besarnya pengaruh agama bagi peningkatan keimanan dan ketaqwaan serta pembentukan moral warga negara telah menjadikan pendidikan agama sebagai mata pelajaran yang wajib bagi semua jenjang pendidikan, dari pendidikan dasar sampai dengan pendidikan tinggi. Keberadaan pendidikan agama sebagai mata pelajaran didukung oleh UUD 1945 dan Pancasila sebagai dasar negara. Pendidikan agama memiliki peranan yang sangat besar karena pendidikan agama dimaksudkan untuk membentuk peserta didik menjadi manusia yang beriman dan bertaqwa kepada Tuhan Yang Maha Esa serta berakhlak mulia. (Undang-Undang Nomor 20 Tahun 2003 Tentang Sistem Pendidikan Nasional, 2003). Maka harapan yang muncul adalah pendidikan agama menjadi tumpuan untuk membentuk moralitas dan kepribadian warga negara yang religius.

Dewasa ini masalah moralitas di kalangan generasi muda khususnya pelajar dan mahasiswa merupakan problem besar. Generasi muda merupakan aset bangsa yang akan menentukan masa depan bangsa. Kenyataannya sekarang, pelajar dan mahasiswa sebagai generasi terpelajar mudah terprovokasi sehingga terjadi tawuran di berbagai sekolah dan perguruan tinggi. Banyaknya kasus-kasus amoral yang dilakukan oleh generasi muda, seperti kasus narkoba, seks bebas, hamil di luar nikah, aborsi, dan lain-lain. Berbagai problema tersebut tidak dapat terpecahkan, melainkan dengan cara kembali kepada ajaran agama yang salah satu caranya dengan mengefektifkan pendidikan agama di sekolah.

Pembentukan kepribadian yang bermoral dan religius atau pribadi yang memiliki keberagamaan (religiusitas), tidak cukup dengan mengandalkan mata pelajaran pendidikan agama yang hanya mendapat alokasi waktu dua atau tiga jam pelajaran pada setiap minggunya. Apalagi adanya stigma yang berkembang bahwa keberhasilan pendidikan agama 
peserta didik merupakan tanggungjawab guru agama menambah permasalahan dalam dunia pendidikan agama Islam di sekolah.

Malik Fadjar menyatakan bahwa pendidikan agama bukan merupakan kegiatan yang terpisah dari aspek-aspek kehidupan masyarakat luas. Sekolah hanya merupakan salah satu wahana yang barangkali bukan utama. Di luar sekolah banyak pihak yang tidak kalah penting peranannya yang ikut memberikan pengaruh terhadap pelaksanaan pendidikan seperti keluarga dan lingkungan di masyarakat. Meskipun keluarga dan masyarakat juga sangat berperan bagi pembentukan kepribadian dan moral anak bangsa, akan tetapi sekolah sebagai lembaga pendidikan secara terencana masih menjadi tumpuan untuk pembentukan watak dan moralitas anak bangsa. (Fadjar, 2005)

Untuk itu maka pada dasarnya pendidikan agama Islam harus mencakup tiga aspek secara terpadu, yaitu: (1) knowing, yakni agar peserta didik dapat mengetahui dan memahami ajaran dan nilai-nilai agama; (2) doing, yakni agar peserta didik dapat mempraktekkan ajaran dan nilai-nilai agama, dan (3) being, yakni agar peserta didik dapat menjalani hidupnya sesuai dengan nilai-nilai dan ajaran agama (Muhaimin, 2009). Mengingat pentingnya pendidikan agama, maka kegiatan pendidikan harus dapat membekali peserta didik dengan kecakapan hidup (life skill atau life competency) yang sesuai dengan lingkungan dan kebutuhan peserta didik.

Untuk mewujudkan ketiga aspek di atas diperlukan perubahan paradigma pendidikan agama di sekolah. Muhaimin menyatakan bahwa perubahan paradigma pendidikan agama di sekolah yang dimaksud yaitu bahwa pendidikan agama bukan hanya tugas guru agama saja, tetapi merupakan tugas bersama antara kepala sekolah, guru agama, guru umum, seluruh aparat sekolah, dan orang tua murid. Jika pendidikan agama sebagai tugas bersama, berarti pendidikan agama itu perlu atau bahkan harus dikembangkan menjadi budaya sekolah, artinya seluruh warga di sekolah membiasakan diri mengamalkan ajaran-ajaran agama di sekolah supaya menjadi kultur atau budaya di sekolah tersebut.(Muhaimin, 2006)

Pengembangan keberagamaan peserta didik melalui budaya agama dalam lingkungan sekolah merupakan upaya untuk menanamkan nilai-nilai ajaran agama kepada siswa dengan tujuan untuk dapat memperkokoh keimanan serta menjadi pribadi yang memiliki kesadaran 
beragama dan berakhlak mulia. Hal ini sangat penting karena kegiatan tersebut merupakan rangkaian kegiatan yang mendukung tercapainya tujuan pendidikan nasional dan dapat mempengaruhi sikap, sifat, dan tindakan siswa secara tidak langsung.

Pengembangan budaya agama di lingkungan sekolah mempunyai landasan yang kokoh baik secara normatif religius maupun secara konstitusional, sehingga tidak ada alasan lagi bagi sekolah untuk mengelak dari upaya tersebut (Muhaimin, 2009). Secara normatif religius, budaya agama dapat dipahami dari firman Allah Swt. dalam QS. al-Baqarah: 208 yang artinya: Hai orang-orang yang beriman, masuklah kamu ke dalam Islam (perdamaian) seluruhnya. Landasan secara konstitusional dinyatakan dalam Permendiknas nomor 22 tentang Standar Isi dalam standar kompetensi dan kompetensi dasar mata pelajaran Pendidikan Agama Islam (PAI) bahwa PAI baik pada jenjang pendidikan dasar maupun menengah antara lain bertujuan untuk mewujudkan manusia Indonesia yang taat beragama dan berakhlak mulia, yaitu manusia yang berpengetahuan, rajin beribadah, cerdas, produktif, jujur, adil, etis, berdisiplin, bertoleransi (tasamuh) menjaga keharmonisan secara personal dan sosial, serta mengembangkan budaya agama dalam komunitas sekolah.

Salah satu faktor yang berperan penting dalam pengembangan budaya agama di sekolah adalah peran aktif komunitas sekolah yaitu kepala sekolah, guru, karyawan, dan siswa. Akan tetapi sebagai pimpinan, kepala sekolah mempunyai andil dan peran terbesar karena di tangan kepala sekolah kebijakan kebijakan tersebut dibuat dan dilaksanakan oleh segenap warga sekolah. Urgensi pengembangan budaya agama di sekolah adalah agar seluruh warga sekolah memperoleh kesempatan untuk dapat memiliki bahkan mewujudkan seluruh aspek keberagamaannya baik pasa aspek keyakinan (keimanan), praktik agama, pengalaman, pengetahuan agama, dan dimensi pengamalan keagamaan. Semua itu dapat diwujudkan melalui berbagai kegiatan keagamaan sebagai wahana dalam upaya menciptakan dan mengembangkan budaya religius di sekolah.

Siswa SMA pada umumnya secara psikologis telah memasuki masa remaja. Tingkat perubahan dalam sikap dan prilaku selama masa remaja sejajar dengan tingkat perubahan fisik. Selama masa remaja awal, ketika perubahan fisik terjadi dengan pesat, perubahan prilaku dan sikap juga berlangsung pesat (Hurlock, 1953). Pada masa itu bagi Santrock 
seorang remaja bisa saja merasa sedang di puncak dunia pada suatu saat namun merasa tidak berharga sama sekali pada waktu berikutnya. Pada masa tersebut, remaja jarang memperhatikan dan mempertimbangkan akibat dari perilaku dan gaya hidupnya. Oleh karena jiwanya yang sedang labil, maka seringkali remaja bersikap dan berprilaku yang tidak sesuai dengan etika, agama maupun adat ketimuran (Santrock, 2007).

Mencermati fenomena yang demikian, maka pembinaan keberagamaan terhadap siswa mutlak dilakukan dalam rangka pendampingan terhadap siswa remaja yang sedang mencari jati dirinya. Hal yang dapat dilakukan untuk itu adalah dengan menciptakan lingkungan sekolah yang islami dan melaksanakan berbagai kegiatan keagamaan serta praktik-praktik keagamaan yang dilaksanakan secara terprogram dan rutin, sehingga sangat memungkinkan membuat siswa berada dalam kondisi terbiasa beragama. Hal semacam ini sangat berdampak positif terhadap kehidupan keagamaan siswa karena pembiasaan dalam beragama dapat meningkatkan kesadaran dalam beragama serta dapat menciptakan suasana ketenangan dan kedamaian bagi yang melaksanakannya atau civitas akademikanya.

Salah satu SMP di Bandung yang telah merespon dengan baik kebijakan tersebut adalah SMPN 10 di Bandung. Sekolah ini dipilih sebagai fokus penelitian, karena sekolah ini merupakan sekolah umum yang biasanya kering dari suasana keagamaan tidak terlihat pada sekolah ini. Sekolah ini juga memiliki siswa dengan agama yang beragam, tetapi tetap mampu mengembangkan suasana keagamaan dengan cukup baik. Pada sekolah ini ditemukan gejalagejala yang cenderung positif.

Berdasarkan hasil pengamatan awal yang dilakukan, didapati bahwa di sisi siswa SMPN 10 Bandung, keberhasilan sekolah dalam menciptakan budaya agama dengan suasana religius yang kondusif sudah cukup baik, terutama dapat dilihat dalam beberapa hal pertama, pada waktu istirahat sudah cukup banyak siswa yang melaksanakan sholat Dhuha. Kedua, siswa melakukan shalat wajib di sekolah dengan berjamaah, sesuai dengan waktu shalat yang berlangsung pada jam sekolah. Ketiga, secara umum siswa sudah punya sikap keagamaan yang cukup baik, hal ini terlihat dengan hormat dan santunnya siswa terhadap guru, karyawan maupun tamu yang hadir di sekolah. Keempat, telah cukup banyak siswa yang mengenakan pakaian muslimah dengan kesadaran sendiri, walaupun bukan pada hari yang 
diwajibkan untuk itu.

Di sisi guru, terdapat gejala antara lain sebagai berikut. Pertama, dalam proses pembelajaran, guru agama nampaknya tidak terlalu terpaku pada selesainya kurikulum saja tetapi telah ada keinginan untuk memberikan pengalaman keagamaan yang lebih banyak kepada siswa. Kedua, pendidikan agama terkesan tidak dinomorduakan dan tidak hanya menjadi tanggung jawab guru agama saja, karena guru-guru lain dan karyawan nampaknya telah merespon positif seluruh kegiatan keagamaan yang dilaksanakan. Masalah penelitian ini difokuskan pada bagaimana pengembangan keberagamaan siswa melalui budaya agama di SMPN 10 di Bandung.

\section{METODOLOGI}

Penelitian ini merupakan jenis penelitian kualitatif. Pendekatan penelitian yang digunakan adalah pendekatan fenomenologis (arti keberadaan) yaitu cara pendekatan untuk memperoleh pengetahuan tentang sesuatu (objek) sebagaimana tampilnya dan menjadi pengalaman kesadaran kita (Moleong, 2005). Penggunaan pendekatan ini disesuaikan dengan tujuan pokok penelitian, yaitu mendeskripsikan pengembangan keberagamaan siswa melalui budaya agama di SMPN 10 di Bandung.

Adapun informan penelitian ini terdiri dari kepala sekolah, seluruh guru yang mengasuh mata pelajaran pendidikan agama Islam, beberapa orang guru selain guru pendidikan agama Islam, dan siswa yang ditentukan kemudian sesuai dengan kebutuhan dan tujuan penelitian. Informan tersebut dipilih berdasarkan tugas dan keterkaitan dengan tema penelitian, dengan menggunakan prinsip "snowball", yaitu penentuan informan penelitian yang semula jumlahnya sedikit, lama- lama menjadi besar (Moleong, 2005). Dalam rangka mengumpulkan seluruh data penelitian yang dibutuhkan dalam penelitian ini secara komprehensif, maka peneliti menggunakan tiga macam teknik pengumpulan data yaitu: wawancara, observasi dan dokumentasi. Selanjutnya data yang telah terkumpul dianalisa secara kualitatif dengan mengikuti teknik analisa data yang dikemukakan oleh Miles dan Huberman, melalui tiga alur kegiatan yang dilaksanakan secara berurutan, yaitu; (1) reduksi data, (2) display data, dan (3) pengambilan kesimpulan/verifikasi dilakukan secara terus menerus selama proses penelitian berlangsung (Miles \& Huberman, 1992). 


\section{HASIL DAN PEMBAHASAN}

\section{Pelaksanaan Pembinaan Keberagamaan Siswa di SMPN 10 Bandung}

Pembinaan keberagamaan siswa yang dimaksudkan di sini adalah usaha yang direncanakan secara sistematis berupa bimbingan, pemberian informasi, pengawasan dan juga pengendalian untuk peningkatan kualitas para siswa, khususnya dalam hal keagamaan dalam menciptakan sikap mental dan pengembangan potensi yang positif sehingga terbentuk keberagamaan yang baik pada diri siswa.

Berdasarkan pengamatan dan wawancara secara langsung dengan kepala sekolah, guru agama, pembina dan siswa, diketahui bahwa penembangan keberagamaan yang dilaksanakan oleh SMPN 10 Bandung adalah dengan melaksanakan berbagai kegiatan keagamaan yang wajib dilaksanakan dan diikuti oleh seluruh civitas akademika sekolah, khususnya siswa yang beragama Islam.

Kegiatan keagamaan yang dilaksanakan di sekolah dalam rangka pengembangan keberagamaan siswa dilaksanakan melalui dua kelompok pelaksana kegiatan keagamaan yaitu sekolah sebagai lembaga pendidikan yang utuh dengan kebijakan-kebijakan yang berkaitan dengan budaya agama di komunitas sekolah dan Rohis (rohani Islam) sebagai jenis kegiatan ekstrakurikuler sekolah yang husus menaungi kegiatan-kegiatan keagamaan lainnya.

Kegiatan keagamaan yang dilaksanakan sekolah sebagai lembaga yang berkomitmen untuk mengembangkan budaya agama di sekolah yang wajib diikuti oleh seluruh warga sekolah dilaksanakan dalam bentuk:

a. Majelis Ta'lim, dengan sub kegiatan; halaqoh, mentoring keagamaan, dan pengajian tilawatil Qu'ran

b. Membaca al-Qur'an 10 menit am pelajaran pertama

c. Membaca surah Yasin pada hari Jum'at

d. Sholat Dzuhur berjama'ah

e. Sholat Dhuha bersama

f. Pelaksanaan Perayaan Hari Besar Islam (PHBI)

g. Pesantren kilat bulan Ramadhan 
h. Baksos (Bakti Sosial)

i. Lomba-lomba Islami

j. Bersalaman dengan guru sebelum masuk sekolah

k. Nasyid media dakwah lewat nada dan syair

1. Pakaian sekolah muslim-Muslimah, pada bulan Ramadhan dan wajib hari Jum'at

Dilihat dari waktu pelaksanaannya, kegiatan keagamaan tersebut ada yang dilaksanakan secara rutin baik secara harian, mingguan maupun tahunan. Kegiatan keagamaan yang dilaksanakan setiap hari antara lain membaca al-Qur'an selama 10 menit pada jam pelajaran pertama, bersalaman dengan guru sebelum masuk sekolah, sholat Zhuhur berjamaah dan sholat Dhuha. Mengingat keterbatasan daya tampung mushalla al-Kautsar SMP Negeri 10 Bandung, khusus untuk sholat Zhuhur berjamaah dan sholat dhuha tidak diwajibkan kepada seluruh siswa untuk melaksanakannya melainkan sesuai kesadaran masing-masing, baik siswa maupun guru. Meskipun demikian ibadah sholat Zhuhur berjamaah tersebut setiap hari selalu dilaksanakan setelah jam pulang sekolah, dan biasanya dipimpin oleh salah seorang guru.

Untuk mendukung terciptanya suasana yang islami dan kenyamanan dalam proses belajar-mengajar, setiap guru dan siswa (khususnya yang beragama Islam) harus selalu berbusana muslim/muslimah, sebagaimana dikemukakan oleh Kepala Sekolah bahwa: Setiap harinya siswa memakai pakaian yang menutup aurat dan untuk siswi yang muslim memakai Jilbab. Semua ini dilakukan untuk menciptakan lingkungan Islami, disiplin, membiasakan diri siswa menutup aurat, dan menciptakan kenyamanan dalam proses belajar-mengajar di kelas. Bukan hanya siswa, namun guru yang beragama Islam pun wajib memakai Jilbab setiap harinya di SMP Negeri 10 Bandung. Di samping kegiatan keagamaan yang bersifat harian, ada juga beberapa kegiatan yang bersifat mingguan, seperti majelis ta'lim (halaqah) bagi anggota Rohis yang dilaksanakan setiap hari Sabtu siang untuk ikhwan dan Jum'at siang untuk akhwat, mentoring keagamaan khusus untuk Semester I kelas VII setiap hari Minggu siang selama tiga bulan (September s.d Nopember), dan tilawatil Qur'an untuk siswa baru kelas VII. Keikut sertaan siswa dalam kegiatan mentoring keagamaan tersebut sangat penting karena $30 \%$ nilai raport untuk mata pelajaran pendidikan agama Islam pada semester I diambil dari 
kehadiran siswa dalam kegiatan mentoring (Wawancara, 18 Juli 2020).

Adapun kegiatan keagamaan yang bersifat tahunan adalah Pelaksanaan Perayaan Hari Besar Islam (PHBI). Kegiatan ini termasuk aktivitas keagamaan siswa yang telah terprogram dengan baik, karena aktivitas keagamaan ini dilaksanakan rutin pada setiap tahunnya. Menurut Wakil Kesiswaan, beliau mengemukakan bahwa: Setiap Perayaan Hari Besar Islam (PHBI) di sekolah atau di luar sekolah diatur pada jadwal tertentu sesuai dengan kesepakatan bersama. Hari besar Islam yang selalu di adakan adalah Maulid Nabi Muhammad Saw., Isra'Mi'raj, Muharram Ekspo, Nuzul Qur'an, dan Pesantren Kilat yang dilaksanakan beberapa hari, di mana siswa akan menjadi panitianya yang dikoordinir oleh guru yang telah ditunjuk berdasarkan kesepakatan bersama. (Wawancara, 17 Juli 2020).

Momentum pelaksanaan PHBI tersebut juga biasanya dimeriahkan dengan beberapa kegiatan lain seperti bakti sosial, lomba-lomba islami seperti madding, nasyid, da'i/da'iyah, kaligrafi dan lain-lain. Dengan demikian, kegiatan-kegiatan PHBI di samping dapat menumbuhkan kesadaran beragama warga sekolah diharapkan dapat mempererat kekompakan dan kebersamaan warga sekolah sebagai sebuah komunitas yang bekerjasama untuk mencapai tujuan-tujuan sekolah.

Dalam rangka pengembangan keberagamaan siswa SMP Negeri 10 Bandung, selain melalui berbagai kegiatan keagamaan yang dilaksanakan oleh pihak sekolah yang wajib diikuti oleh seluruh siswa, sekolah ini juga melaksanakan kegiatan keagamaan melalui Rohis (Rohani Islam) yaitu organisasi ekstrakurikuler kesiswaan yang membidangi kegiatan keagamaan. Adapun kegiatan yang dilakukan rohis, yang wajib diikuti oleh siswa yang mengikuti organisasi Rohis SMP Negeri 10 Bandung. adalah sebagai berikut:

a. Mabit (malam bina iman dan taqwa) dengan kegiatan taujih, qiyamul lail, tadarus Qur'an, muhasabah, sholat berjama'ah, dan sebagainya

b. Rihlah, berkunjung ke tempat bersejarah dan yang lain dalam rangka i'tibar

c. Riadhoh dan Dauroh, kegiatan olah raga dan pelatihan dalam rangka pendalaman kompetensi organisasi dan keagamaan

d. Mukayyam, kegiatan berkemah untuk melatih kemandirian dengan kegiatan Islami

e. Kajian keislaman dan kajian kemuslimahan 


\section{f. Outbond}

g. Kegiatan indoor

Berbagai kegiatan keagamaan tersebut di atas, baik yang dilaksanakan oleh sekolah sebagai lembaga pendidikan maupun yang dilaksanakan oleh Rohis sebagai organisasi ekstrakurikuler sekolah, diharapkan dapat menjadi jalan untuk menciptakan sikap mental dan berkembangnya potensi yang positif pada diri siswa, sehingga dapat memicu ketaatan siswa terhadap ajaran agama Islam dan dijadikan sebagai pedoman dalam kehidupan sehari-hari.

\section{Upaya Kepala Sekolah dalam Pengembangan Budaya Agama}

Budaya agama yang ada di SMP Negeri 10 Bandung merupakan gagasan dari kepala sekolah, hal ini dimaksudkan agar sekolah yang notabene-nya umum bisa sejajar dengan madrasah bahkan lebih baik dalam hal pengembangan nilai agama Islam. Dalam pengembangan budaya agama di sekolah ini kepala sekolah merupakan figur yang pertama memberikan tauladan kepada semua warga sekolah.

Budaya agama sendiri menurut kepala sekolah (Wawancara, 22 Juli 2020) mempunyai makna prilaku seseorang yang mempunyai nilai ibadah sebagai pondasi dan sebagai salah satu landasan dalam menjalankan agama Islam, karena budaya agama Islam sebagai pondasi dan landasan dalam menjalankan agama Islam, maka penting budaya agama ini dilaksanakan, dikembangkan dan dipertahankan di sekolah ini, budaya agama yang kepala sekolah gagas dan sudah dijalankan oleh semua warga sekolah adalah memakai jilbab, berbusana muslim pada bulan Ramadhan dan bulan lainnya, pemberian Seni Baca al-Qur'an pada kelas satu dan tafsir pada kelas dua.

Pengembangan secara praktek dilaksanakan langsung oleh siswa dan warga sekolah dalam kegiatan hari-hari besar Islam, juga siswa diajak secara langsung untuk ke lapangan mengadakan kegiatan sosial seperti ke panti asuhan, bakti sosial dengan memberikan sumbangan ke fakir miskin sebagai wahana mereka untuk bisa merasakan nilai yang ada didalamnya dan menjadikan siswa bersyukur, untuk dana di-support dari sekolah. Pengembangan budaya agama juga dilakukan dengan memberikan motivasi sehingga nantinya siswa melakukan suatu pekerjaan didasari dengan nilai agama dan muncul dari keinginannya untuk melaksanakan ajaran-ajaran agamanya.

Dalam pengembangan budaya agama di SMP Negeri 10 Bandung, kepala sekolah 
menggunakan beberapa strategi pengembangan budaya agama. Di antara upaya pengembangan budaya agama yang dilakukan oleh kepala sekolah adalah melakukan perencanaan progam, memberikan teladan kepada guru, siswa, karyawan dan semua komunitas yang ada di sekolah, kepala sekolah selalu andil dalam kegiatan keagamaan, dan evaluasi terhadap progam yang dijalankan baik secara terstruktur dan kondisional (Wawancara, 22 juli 2020).

\section{Dukungan Warga Sekolah dalam Pengembangan Keberagamaan Siswa melalui Budaya} Agama

Untuk dapat mewujudkan sebuah budaya yang baik di sekolah yang sesuai dengan visi, misi sekolah maka secara tidak langsung sekolah memerlukan dukungan dari semua komponen yang ada, terutama warga sekolah yang meliputi, kepala sekolah, para guru, siswa, dan karyawan sekolah. Mereka dalam bahasa manajemen disebut sebagai pelanggan internal pendidikan (Stephen, 1993: 6). Semua jenis pelanggan ini adalah hal penting yang harus dikenali oleh lembaga pendidikan atau kepala sekolah untuk kerjasama antara supervisor dan pelanggan pendidikan agar menghasilkan lulusan yang dapat memuaskan para pelanggan pendidikan. Agar kualitas pendidikan dapat ditingkatkan, maka diperlukan pelibatan secara optimal semua komponen tersebut.

Pelibatan secara total yaitu melibatkan secara penuh semua komponen sekolah, baik komponen internal maupun eksternal. Tujuannya tidak lain agar mutu atau kualitas sekolah tersebut dapat ditingkatkan secara terus menerus. Dalam hal ini, pelibatan tersebut bertujuan mewujudkan dan meningkatkan budaya agama di sekolah. Dalam pengembangan budaya agama di SMP Negeri 10 Bandung, warga sekolah memberikan respon positif terhadap kebijakan-kebijakan kepala sekolah dalam mengembangkan budaya agama, meliputi beberapa budaya agama yang sudah ada di SMP Negeri 10 Bandung. seperti halnya pemakaian jilbab dan berbusana muslim pada waktu Ramadhan dan hari jum'at, sholat berjamaah, mengucap salam, aktif dalam kegiatan Peringatan Hari Besar Islam (PHBI) dan kegiatan-kegiatan keagamaan lain dalam naungan Rohis (Rohani Islam).

Dukungan warga sekolah terhadap pengembangan budaya agama dapat dilihat dari beberapa aspek seperti keikutsertaan semua warga sekolah untuk menjalankan peraturan dan kebijakan yang dibuat kepala sekolah dalam hal pengembangan budaya agama di SMP Negeri 
10 Bandung.

Sikap dukungan guru dan siswa dalam pengembangkan budaya agama agak berbeda, letak perbedaannya tidak banyak, hanya berbeda dalam beberapa hal saja. Guru dalam mendukung budaya agama lebih kepada keinginan serta harapan siswa bisa menjalankan dan melaksanakan budaya agama dengan baik dan memberikan point lebih kepada siswa yang menjalankan budaya agama di sekolah dengan baik dan konsisten. Sedangkan pada siswa dukungan yang nampak terlihat adalah ketika siswa bisa menjalankan dan melaksanakan budaya agama dengan baik, mematuhi peraturan yang ada, dan bisa menjadi teladan bagi sesama temannya. Adapun wilayah perbedaan dukungan warga sekolah terhadap pengembangan budaya agama di SMP Negeri 10 Bandung adalah dapat dilihat dari hasil wawancara peneliti dengan koordinator ekstrakulikuler dan pembina dari Rohis (Rohani Islam), beliau mengungkapkan bahwa: “Dukungan warga sekolah terhadap pengembangan budaya agama dapat dilihat dari berbagai aspek, diantaranya adalah: dari aspek dukungan kepala sekolah, dari aspek dukungan sesama guru, dukungan sesama siswa dan dukungan semua karyawan. Akan tetapi semua warga sekolah disini mendukung terhadap budaya agama dan saya rasa budaya agama di sekolah ini berjalan sangat maksimal" (Wawancara, 28 Juli 2020).

\section{a. Dukungan Kepala Sekolah}

Dukungan kepala sekolah terhadap pengembangan budaya agama dapat dirasakan oleh semua warga sekolah, kepala sekolah dalam mengembangkan budaya agama sangat konsisten. Kepala sekolah dalam mengembangkan budaya agama selalu melihat keberhasilan ke depan dengan melakukan inovasi terhadap progam serta kebijakan yang dirasa perlu diperbarui.

Dukungan kepala sekolah dalam mengembangkan budaya agama bisa dilihat dari sikap kepala sekolah yang nampak seperti ada usaha untuk mengembangkan budaya agama, ada usaha kepala sekolah untuk mempertahankan budaya agama serta adanya usaha kepala sekolah untuk menjadikan sekolah dengan suasana islami melalui budaya agama yang ada di SMP Negeri 10 Bandung.

Dalam wawancara peneliti dengan kepala sekolah ketika peneliti menanyakan tentang 
dukungan kepala sekolah terhadap pengembangan budaya agama, beliau mengungkapkan bahwa: “Untuk mengembangkan dan menjalankan budaya agama saya akui sulit, semua itu butuh proses, tetapi saya yakin jika kita berusaha pasti semua akan berhasil, saya tetap optimis pngembangan budaya agama di sekolah ini tahun demi tahun akan mengalami perubahan yang signifikan terlebih pada prilaku akhlak siswa akan mencerminkan nilai-nilai Islam, serta dapat melaksanakan ajaran dan syariat Islam dengan baik" (Wawancara, 22 Juli 2020).

Adapun dukungan kepala sekolah terhadap budaya agama dapat dilihat juga dari loyalitas, semangat, prilaku sehari-hari serta saling mengingatkan dan saling memberi masukan kepada guru-guru terkait budaya agama yang ada di sekolah ini.

b. Dukungan Sesama Guru

Dalam dukungannya terhadap pengembangan budaya agama di SMP Negeri 10 Bandung, guru-guru mempunyai dukungan yang tinggi. Hal tersebut bisa diketahui dari ungkapan salah satu guru pendidikan agama Islam, beliau mengungkapkan bahwa: "Diantara sesama guru disini membuat jalinan ikatan emosional yang tinggi, dalam mengontrol siswa dan mengembangkan lembaga ini. Kalau dalam bidang pengembangan budaya agama yang biasa guru-guru lakukan sebagai bentuk dukungan adalah selalu memberikan motivasi kepada siswa, dan saling menegur juga mengingatkan sesama guru ketika ada salah satu di antara kita yang sedikit menyimpang dari pengembangan budaya agama" (Wawancara, 28 Juli 2020).

Bentuk dari dukungan guru dalam mendukung pengembangan budaya agama juga bisa dilihat dari guru-guru yang memeberikan masukan secara langsung kepada kepala sekolah dan kepada wakasis terhadap pengembangan budaya agama. Dukungan terhadap siswa dalam mengembangkan budaya agama dapat dilihat dari pemberian nilai dan hadiah kepada siswa yang berani menjalankan budaya agama dengan baik serta berani memonitoring sesama temannya di luar sekolah (di kos-kosan). Hal tersebut sesuai dengan hasil wawancara peneliti dengan guru PAI, mengemukakan bahwa: "Dalam mendukung budaya agama di sekolah, guru-guru sangat dukungan yaitu dengan melakukan suatu tindakan yang sama, kepada anak-anak saya dan guru lainnya memberikan penghargaan kepada siswa yang benar-benar berprilaku baik saya akan mengumumkan kepada teman lainnya contohlah si A si A ini bagus 
dll. Secara tidak langsung maka siswa yang lain berlomba-lomba untuk menjadi yang terbaik. Pada awal masuk sebelum melaksanakan pembelajaran, pertamakali yang saya berikan adalah motivasi" (Wawancara, 28 Juli 2020).

Dari hasil wawancara yang tersebut diatas, dapat dipahami bahwa dalam pengembangan budaya agama, semua dewan guru yang ada di sekolah ini sangat mendukung dan bentuk dukungan yang dilakukan adalah dengan membuat jalinan emosiaonal yang tinggi terhadap budaya agama yang ada serta memberikan nilai tersendiri bagi siswa yang menjalankan budaya agama dengan baik di sekolah maupun di luar sekolah.

c. Dukungan Sesama Siswa

Dalam mendukung budaya agama di sekolah, yang dilakukana siswa adalah membangun komitmen bersama, antara sesama siswa saling mengingatkan jika ada yang melanggar. Hal ini sesuai pemaparan salah satu siswa kelas tiga yang bernama Andin, dia mengungkapkan bahwa: “Kita warga sekolah saling mengingatkan jika teman kita melanggar peraturan dan ketentuan yang telah dijalankan. Misalnya: pada waktu pelaksanaan sholat jumat ada yang tidak segera menuju ke mushalla kita menegur dan mengajaknya secara halus, dan akhirnya teman saya itu mau dan segera menuju ke mushalla" (Wawancara, 28 Juli 2020).

Pernyataan Andin juga sama dengan pernyataan salah satu siswa kelas satu yang bernama Kharisma, dia juga mengungkapkan bahwa: "Kita sesama teman cewek saling mengingatkan dan berusaha menjalankan budaya yang ada di sekolah ini misalnya pada hari jum'at semua anak perempuan disuruh mengikuti kegiatan tambahan yaitu keputrian, kegiatan ini dimaksudkan agar siswi-siwi yang ada di SMP Negeri 10 Bandung, mempunyai pribadi muslimah sebagai seorang wanita yang memiliki pribadi keibuan" (Wawancara, 28 Juli 2020).

Dari hasil wawancara peneliti dengan Zunaedi, salah satu siswa kelas dua dia juga mengungkapkan bahwa: "Sesama siswa baik kelas dua maupun kelas satu bahkan kelas tiga kita dianjurkan unutk saling mengingatkan satu sama lainnya. Lebih lebih terhadap sholat, jika sudah datang waktu dhuhur kita bersama-sama menuju musolla untuk melakukan sholat dhuhur bersama, kita juga saling mengingatkan ketika ada yang tidak menyapa ketika ketemu, kita selalu mengingatkan dengan mengawali mengucap salam dan menebarkan 
senyuman" (Wawancara, 28 Juli 2020).

Dalam pelaksanaan budaya agama di SMP Negeri 10 Bandung, sebenarnya budaya agama tersebut sudah ditanamkan semenjak awal pada waktu siswa duduk di kelas satu. Melalui teladan kakak kelas dalam pelaksanaan orientasi siswa, para senior sudah menanamkan senyuman dan sapaan ketika bertemu semua warga sekolah di SMP ini.

Dapat dipahami bahwasanya dukungan warga sekolah dalam hal ini sudah terlihat semenjak awal ketika siswa baru mulai bergabung menjadi warga SMP Negeri 10 Bandung, hal tersebut secara langsung merupakan bentuk dari dukungan yang dilakukan siswa terhadap pengembangan budaya agama yang ada di SMP Negeri 10 Bandung.

Dukungan yang terakhir yang dapat peneliti amati adalah siswa-siswi di SMP Negeri 10 Bandung selalu melaksanakan dan mengembangkan budaya agama di sekolah dengan baik. Dukungan yang nampak mereka laksanakan bersama adalah patuh terhadap kebijakan kepala sekolah dalam pengembangan budaya agama ini, seperti: siswa-siswi mengenakan busana muslim dengan baik pada hari Jum'at dan Ramadhan, selalu melaksanakan sholat berjamaah, membudayakan senyum sapa, aktif terhadap kegiatan keagamaan serta mengikuti Tarawih berjamaah di sekolahan.

Dari ungkapan tersebut di atas terlihat bahwa salah satu dukungan siswa-siswi terhadapa pengembangan budaya agama adalah dengan cara melaksanakan ketentuan yang telah ada dan dijalankan di sekolah seperti halnya mengucap salam, saling menyapa, mengikuti kegiatan keagamaan sebagai wujud dari dukungan siswa-siswi terhadap pengembangan budaya agama di SMP Negeri 10 Bandung.

\section{d. Dukungan Sesama Karyawan}

Semua karyawan yang ada di SMP Negeri 10 Bandung sangat mendukung terhadap pengembangan budaya agama yang terlaksana, dukungan yang terlihat adalah pertama, mengingatkan siswa jika ada siswa yang melanggar. Kedua, memberikan laporan kepada guru jika siswa yang diperingatkan tidak menghiraukan. Ketiga, para karyawan juga melaksanakan budaya agama yang ada di SMP Negeri 10 Bandung.

Hal tersebut sesuai dengan pemaparan satpam di sekolah ini, dalam wawancara peneliti beliau mengungkapkan bahwa:Salah satu dukungan saya terhadap budaya agama di sekolah, 
yaitu saya mengabdikan diri dan bekerja dengan baik, saya akan memantau prilaku anakanak di luar kelas yang masih dalam lingkup sekolah. Ketika ada anak yang melanggar normanorma yang ada saya langsung menegur dan jika ada siswa yang tidak menghiraukan, maka saya mencatat namanya dan melaporkan kepada pihak sekolah baik guru maupun BP" (Wawancara, 28 Juli 2020).

Dalam pelaksanaan budaya agama dukungan karyawan terhadap pengembangan budaya agama sangat tinggi. Hal tersebut terbukti ketika peneliti pada hari jum'at mengikuti Yasinan yang diadakan oleh sekolah. Yang terlihat dari pengamatan peneliti adalah cleaning servis, satpam, serta sebagian karyawan TU juga masih ada di sekolah untuk memberikan andil secara tidak langsung terhadap kegiatan yasinan tersebut.

Dukungan karyawan terhadap pengembangan budaya agama nampak terlihat juga dari prilaku yang menghargai dan menghormati semua orang yang bertamu di sekolah dan semua warga sekolah. Hal ini sesuai dengan hasil wawancara peneliti dengan koordinator laboratorium komputer, beliu mengungkapkan bahwa: "Sikap saling menghormati dan menghargai yang kita lakukan di sekolah adalah bentuk keinginan kami untuk mendukung progam kepala sekolah serta yang lebih penting kami bisa menjalankan segala peraturan bukan atas dasar paksaan tetapi kesadaran kami masing-masing dan hal ini saya rasa sesuai dengan budaya agama yang digagas oleh kepala sekolah yang selanjutnya sudah dijalankan oleh semua warga sekolah" (Wawancara, 28 Juli 2020).

Dari hasil wawancara menunjukkan bahwa dukungan karyawan terhadap pengembangan budaya agama adalah melalui prilaku yang sesuai dengan norma yang berlaku di sekolah serta terhadap siswa selalu bekerja sama dengan pihak sekolah untuk memantau prilaku siswa dalam lingkungan sekolah setiap harinya.

\section{PENUTUP}

Berdasarkan hasil pembahasan dalam penelitian ini, maka dapat disimpulkan bahwa pelaksanaan pengembangan keberagamaan siswa melalui budaya agama di SMP Negeri 10 Bandung telah berjalan dengan baik dan terprogram, baik yang dilaksanakan oleh sekolah sebagai lembaga pendidikan yang utuh dengan kebijakan- kebijakan yang berkaitan dengan budaya agama di komunitas sekolah maupun kegiatan yang dilakukan oleh Rohis (Rohani 
Islam) sebagai jenis kegiatan ekstrakurikuler sekolah yang khusus menaungi kegiatankegiatan keagamaan lainnya. Keberhasilan ini dapat dicapai karena adanya upaya dari kepala sekolah dan dukungan seluruh warga sekolah dengan cara menunjukkan komitmennya masing-masing yang berlangsung secara bersama-sama dan saling mendukung satu sama lain.

\section{DAFTAR PUSTAKA}

Undang-Undang Nomor 20 Tahun 2003 Tentang Sistem Pendidikan Nasional, (2003).

Fadjar, A. M. (2005). Holistika Pemikiran Pendidikan, ed. Raja Grafindo Persada.

Hurlock, E. B. (1953). Developmental psychology. McGraw-Hill.

Miles, M. B., \& Huberman, A. M. (1992). Analisa Data Kualitatif, (diterjemahkan oleh Tjetjep Rohendi Rohidi). UI-Press.

Moleong, L. J. (2005). Metode Penelitian Kualitatif. Remaja Rosdakarya.

Muhaimin. (2006). Nuansa baru pendidikan Islam: mengurai benang kusut dunia pendidikan. Divisi Buku Perguruan Tinggi, RajaGrafindo Persada.

Muhaimin. (2009). Rekonstruksi pendidikan Islam: dari paradigma pengembangan, manajemen kelembagaan, kurikulum hingga strategi pembelajaran. Raja Grafindo Persada.

Santrock, J. W. (2007). Child development. McGrow. 